\title{
The Leading Role of Economics in Vietnamese Social Sciences and Humanities: A Brief Review
}

\author{
Nguyen Thanh Nhan \\ Foreign Trade University, Hanoi, Vietnam \\ SSHPA Data Team, AI for Social Data Lab, Hanoi Vietnam
}

Ha Noi, January 1, 2020

Economics has been the most prolific field in Vietnam's social science and humanities for not only the constant increase in publication output but also quality of articles. Economics is also a trend-setting field in terms of interdisciplinary research and international publishing. However, the numbers produced by Social Science and Humanities Peer Awards (SSHPA) database have shown the unproportionate ratio between the number of lecturers and publications in leading economic universities, which suggest government to take prompt actions in improving lecturer's scientific publishing productivity. These points have been argued in "Chapter 4 - Economics: The trend-setting field" written by Vu, Tran, Hoang, \& Nguyen (2019) in "The Vietnamese Social Science at Fork in the Road" edited by Vuong \& Tran ( 2019) and published in October 2019 by Sciendo, Walter de Gruyter.

Thanks to the advanced technology and statistical analysis of micro datasets, the number of articles increased during the 2008-2018 period. The number of studies related to Economics had always been stable with an average of 91 articles per year from 2016 to 2018 . In 2018, the number of articles published in Economics was 98, accounting for the largest proportion compared to the remaining fields. Articles related to Economics were published in journal with high impact factor. The top ten articles published in highest impact factor journals were also provided in the chapter. Especially, there was a contribution of female Vietnamese author, Kim Huong Trang to the publication in Journal of International Business Studies published by Palgrave MacMillan Ltd (JIF = 7.724) (Nguyen \& Kim, 2019).

The research team also indicates the recently rising trend of interdisciplinary research in Vietnam; nine out of ten articles published in highest impact factor journals share four main characteristics: co-authorship; foreign authors participation; crossed affiliation; and interdisciplinary nature of research projects. Interdisciplinary research not only creates sustainable networks between Vietnamese scholars and foreign colleagues but also enhances the research performance in the economics discipline (Ho, Nguyen, Vuong, \& Vuong, 2017; Nguyen, 2019). The out-performing scientific production of Economics has encouraged the academic development and cooperation between Vietnam and foreign countries in many other scientific fields.

The data in SSHPA shows that there is a preference in choosing the publisher of Vietnamese authors; the number of articles published in journals of Elsevier, Taylor \& Francis, 
Wiley, and Springer contributes to nearly $80 \%$ of the total articles. Many journals of these publishers are mentioned in the prestigious Social Sciences and Humanities journal list of the National Foundation for Science and Technology Development (NAFOSTED) (Vuong, 2019). However, $\mathrm{Vu}$ et al. (2019) find out a movement to newly-established publishers because of their quick process in decision making, publication and open process mechanism.

In addition, this article also hints at the low contribution of economic lecturers to the scientific research output. Foreign Trade university is a typical example, as only four articles related to Economics were published despite having approximately 70 lecturers. The problem urges the governmental and institutional leaders to take prompt action for increasing the scientific research productivity of economic lecturers. Another concerning problem is that many students mistaken the number of economics related programs is proportional to the number of publications in Economics.

Through this article, I obtained a general overview of current situation of scientific performance related to Economics in many universities nowadays. The statistics clearly show an increase in the number of publications related to Economics during 2008 and 2018. Being the trend-setter in interdisciplinary research and timely integration of foreign publishing practices, Economics has provided good signs for me to hope that Vietnamese authors will create some impacts on the global scientific performance. However, some improvements need to done. The scientific productivity of lecturers in economic universities has to be enhanced to maintain public trust (Vuong, 2018, 2019). Also, government's financial supports, adequate data policies, and open access databases are inevitably essential to promote scientific development (Ho et al., 2019; Vuong, Ho, Nguyen, \& Nguyen, 2019; Vuong et al., 2018; Nguyen, Ho, Nguyen, \& Vuong, 2019; Vuong \& Nguyen, 2016; Vuong, 2016; Vuong, Ho, Vuong, et al., 2019).

\section{References}

Ho, La, Nguyen, Vuong, Nghiem, Tran, ... Vuong. (2019). Health Care, Medical Insurance, and Economic Destitution: A Dataset of 1042 Stories. Data, 4(2), 57. https://doi.org/10.3390/data4020057

Ho, T., Nguyen, H., Vuong, T.-T., \& Vuong, Q.-H. (2017). On the Sustainability of CoAuthoring Behaviors in Vietnamese Social Sciences: A Preliminary Analysis of Network Data. Sustainability, 9(11), 2142. https://doi.org/10.3390/su9112142

Nguyen, M.-H. (2019). How to "Gain a Head Start by Taking a Shortcut" in Vietnamese Social Sciences? SSRN Electronic Journal. https://doi.org/10.2139/ssrn.3484444 
Nguyen, M.-H., Ho, M.-T., Nguyen, Q.-Y. T., \& Vuong, Q.-H. (2019). A Dataset of Students' Mental Health and Help-Seeking Behaviors in a Multicultural Environment. Data, 4(3), 124. https://doi.org/10.3390/data4030124

Nguyen, Q., \& Kim, H. T. (2019). Promoting adoption of management practices from the outside: Insights from a randomized field experiment. Journal of Operations Management, 65(1), 48-61. DOI: 10.1016/j.jom.2018.11.001.

Vu, T.-H., Tran, T., Hoang, P.-H., \& Nguyen, M.-H. (2019). Chapter 4. Economics: The trend-setting field. In Q.-H. Vuong \& T. Tran (Eds.), The Vietnamese Social Sciences at a Fork in the Road (pp. 80-97). https://doi.org/10.2478/9783110686081-009

Vuong, Q. (2019). The harsh world of publishing in emerging regions and implications for editors and publishers: The case of Vietnam. Learned Publishing, 32(4), 314-324. https://doi.org/10.1002/leap.1255

Vuong, Q. H. (2016). Data on Vietnamese patients' behavior in using information sources, perceived data sufficiency and (non)optimal choice of health care provider. Data in Brief, 7, 1687-1695. https://doi.org/10.1016/j.dib.2016.04.066

Vuong, Q.-H. (2018). The (ir)rational consideration of the cost of science in transition economies. Nature Human Behaviour, 2(1), 5-5. https://doi.org/10.1038/s41562-017$0281-4$

Vuong, Q.-H. (2019). Breaking barriers in publishing demands a proactive attitude. Nature Human Behaviour, 3(10), 1034-1034. https://doi.org/10.1038/s41562-019-0667-6

Vuong, Q.-H., \& Nguyen, T.-K. (2016). Data on Vietnamese patients' financial burdens and risk of destitution. Data in Brief, 9, 543-548. https://doi.org/10.1016/j.dib.2016.09.040

Vuong, Q.-H., \& Tran, T. (Eds.). (2019). The Vietnamese Social Sciences at a Fork in the Road. https://doi.org/10.2478/9783110686081 
Vuong, Q.-H., Ho, M.-T., Nguyen, H.-K. T., \& Nguyen, M.-H. (2019). The trilemma of sustainable industrial growth: Evidence from a piloting OECD's Green city. Palgrave Communications, 5(1), 156. https://doi.org/10.1057/s41599-019-0369-8

Vuong, Q.-H., Ho, T. M., Vuong, T.-T., La, V.-P., Hoàng, N. M., \& Ho, T. M. (2019). Comparative views on research productivity differences between major social science fields in Vietnam: Structured data and Bayesian analysis, 2008-2018 [Preprint]. https://doi.org/10.31219/osf.io/gb3wp

Vuong, Q.-H., La, V.-P., Vuong, T.-T., Ho, M.-T., Nguyen, H.-K. T., Nguyen, V.-H., ... Ho, M.-T. (2018). An open database of productivity in Vietnam's social sciences and humanities for public use. Scientific Data, 5, 180188.

https://doi.org/10.1038/sdata.2018.188 